\title{
Normative Powers and European Foreign Policy in a Minilateralist World
}

\author{
Gunther HELLMANN
}

The title of this article which was initially presented as a Keynote address to the 36th Annual Conference of the European Union Studies Association-Japan will probably cause irritation-and it is meant to cause such irritation. It is the pointed version of my answer to the invitation to address the meeting with a special emphasis on European foreign policy and constructivist theories. The title plays with three (more or less well established) concepts - "normative power", "European foreign policy" and "multilateralism". It does so in order to identify what I consider to be a central problematique of contemporary European politics.

As the following discussion will show I will use these concepts in a particular fashion-esp. by expanding their uses compared to how these concepts have come to be understood in the context of International Relations discourse in general and the study of European Union politics in particular. The purpose of this move is to arrive at what I would hope is a cogent description of the "state of the European Union" in a world which is - as German foreign minister Frank Walter Steinmeier often puts it these days - "out of joint" (Steinmeier 2015). Another way of putting this in more academic terms is to suggest that I will choose a strategy of conscious defamiliarization of established disciplinary language games in order to offer a different way of theorizing EUropean foreign policy.

The background or setting for such a strategy of defamiliarization 
can be summarized by reference to two stark and contradictory descriptions of Europe's situation which lie apart by only two years, one by the most influential IR theorist, one by a young conservative writer. In what was probably his last interview Kenneth Waltz in March 2013 (Waltz and Simon 2013) was asked to analyze the contemporary global political order. The interview ended with a discussion of "the issue of rising powers" in the context of Europe. Waltz summarized his main thesis right at the start: "When major powers decline they become uninteresting. Just like Athens and Sparta after the rise of Rome, Germany and France are uninteresting now." He then poked fun at "people $(\cdots)$ arguing how wonderful it is that Europe has become pacific, but do these people know any history? An inevitable consequence of once (sic!) great powers heading towards decline is that they become more peaceful. We should expect nothing less of them." The interview then closed with the question whether the European Union would "represent the end or mitigation of anarchy in Europe" or whether we should "expect the return of power competition in Europe". It is worth quoting Waltz's answer in full:

Anarchy is the basic cause and condition of international politics and so it is present in Europe. But it does not have the same implications. Remember, Norway and Sweden split without war or fuss. In any case, who cares about anarchy in Europe? What is there to mitigate? It has already been mitigated. Countries fight, decline and become more peaceful. In any case, Europe is not controversial. It will only become interesting when it forms a genuinely unified sovereign country, but this is not going to happen any time soon. Europe is boring and affluent. It is in a happy position, so enjoy it." (ibid.)

The contrast is provided by a young and conservative American writer who lives in Paris and who obviously has stronger feelings about Germany. Right after the terrorist attacks in Paris on 13 November 
Normative Powers and European Foreign Policy in a Minilateralist World (HELLMANN)

2015 James Poulos (2015) had this to say about France being "at war with Germany":

The sheer outrage of the attacks has reminded even Hollande of how unnatural and belittling German control over French budgeting has come to feel. "The security pact takes precedence over the stability pact," as he announced at a joint session of parliament. ( $\cdots$ ) France's nationalistic insurgency is just the beginning. ( $\cdots$ ) Merkel's approach to keeping the eurozone intact was viewed by many Europeans as everything from bunk economics to moral bankruptcy, and its dead yet grasping hand was invasive enough to stir up memories of the deceptively distant Nazi occupation. ( $\cdots$ ) A turn in France toward popular force, and against bankers' restraint ( $\cdots)$ would be a decisive blow to Merkel's reign in Europe. No other nation in Europe is consequential enough to have anchored the $\mathrm{EU}$ as an equal partner with Germany, and no other can hold its lesser members together with an alternate worldview as firmly established as Germany's own. ( $\cdots$ ) If history was made that bloody night in Paris, it could well be France's return to dominance.

This is the setting - and the contrast could not be starker. Here the grand old realist of IR theory declaring “boring” European peace, there the young polemical conservative seeing France and Germany approaching war. These assessments lie just two and a half years apart-but for Europe they look like an era.

In the following I will develop my alternative description of the state of Europe step by step by exploring the concepts "normative powers", "European foreign policy" and "minilateralism" and how they hang together in circumscribing one of the central problematiques of contemporary European politics. 


\section{„Normative Power Europe“- and other forms of „normative power(s)“}

Scholars in the field of European studies are well familiar with the debate about "Normative Power Europe" which is associated most closely with an article by Ian Manners (Manners 2002). However, practitioners and non-academics may not as easily understand what the concept means because ordinary language uses of the three words "normative" "power" and "Europe" would render their combination in a single concept to be, at a minimum, in need of explanation. "Europe" is the easiest part-despite the fact that the geographical and the political signifiers are no longer in sync. A quick look at the map and the borders of the $\mathrm{EU}$ on the hand and the geographical boundaries of the European continent on the other shows this. It is remarkable indeed that the widespread identification of the word "Europe" with the region encompassing only the EU has largely superseded the historical and geographical reference to Europe as a region which naturally encompasses Russia - or at least parts of it. However, even if we take the delimitation of "Europe" to the political entity of the EU for granted the reference to a union of nation states in combination with "power" would still mark an unusual collocation because the ordinary language games of great power politics normally reserves this particular use of the power signifier for "coherent" political units such as nation states. In other words, the very fact that "EUrope" is by now widely assimilated to other political entities in "power" terms reflects on the institutional maturation which the EU has gone through.

From an ordinary language point of view the most irritating aspect of the neologism "Normative Power Europe" is the combination of "normative" and "power" because the normativity implicitly insinuated is one which associates "power" with some general good-or, as Knud Erik Jørgensen and Katie Laatikainen have put it early on: that it easily 
aligns itself with the self-image of the EU "as a force of goodness in international society" (Jørgensen \& Laatikainen 2004: 15-16; see also Sjursen 2006). When Manners invented "Normative Power Europe" he was well aware of the counterintuitive combination of the adjective "normative" and the concept of "power" because the second part of the title of his initial article already posed the question whether "normative power Europe" is a "contradiction in terms" (Manners 2002).

As it turns out, the purely rhetorical quality of the question was quickly revealed when Manners explained his understanding of "normative", among others, with a reference to "the ability to define what passes for 'normal' in world politics" (Manners 2002: 236, 240). Tellingly, this "ability to shape conceptions of 'normal' in international relations" (Manners 2002: 239) was not even mentioned among the different meanings of normative power ten years later when Manners revisited the "Normative Power Europe" debate he had started. "Three particular meanings" of normative power "in EU studies" were now listed instead: (1) uses in "normative theory, that is how we judge and justify truth claims in social science"; (2) normative power "as a form of power (pouvoir) that is ideational rather than material or physical"; and (3)normative power "as a characterization of an ideal type of global actor (puissance)" (Manners 2013: 308-309). Among these meanings the initial definition - "the ability to define what passes for 'normal' in world politics" had completely disappeared.

One of the lessons to be learned from this naming exercise is that "normative power" is what in semiotics is called an "empty signifier"ie. "a signifier with a vague, highly variable, unspecifiable or non-existent signified" which "means different things to different people: they may stand for many or even any signifieds" (see Chandler 2015). In hindsight Manners' neologizing effort has turned out to be a smart move nevertheless in at least three respects. The usual citation indices show that it helped Manners' academic career (see Google Scholar). 
Moreover, as the resonance among practitioners in Brussels has shown, "Normative Power Europe" also appealed tremendously to the self-image of European foreign policy decision-makers. As former High Representative Javier Solana put it: "The EU has responsibility to work for the 'global common good'. That is a fitting way of describing the EU's global role and ambition" (Aggestam 2008: 6). "Normative Power Europe", in other words, enabled practitioners to do what the modern father of realism, Hans Morgenthau, had attributed to "all nations" - ie. that they "are tempted $(\cdots)$ to clothe their own particular aspirations and actions in the moral purposes of the universe" (Morgenthau 1985 [1948]: 13). Finally the concept helped to push-start a whole new "Normative Powers" (NP) industry or "Normative Powers research complex". In part this included the proliferation or recovery of concepts with a certain family resemblance - such as the older "civilian power Europe" (Bull 1982), "ethical power Europe" (Hyde-Price 2008) or "liberal power Europe" (Wagner 2015). But it also included other neologisms which were supposed to mark counterpoints - such as "Idiot Power" (Carta 2014), "Market power" (Damro 2012), "Integrative Power" (Koops 2011) or “Normal Power” (Wood 2009; Pardo 2011).

One of the reasons why this research program looked attractive to start a new "debate" among EU scholars, especially in EUrope itself, was that it was placed at the center of liberal/constructivist theorizing - in other words, it was not framed in the stereotypical "realist" language (which is largely marginalized in EUropean IR anyhow). Moreover, the attractiveness of combining "normative" with "power" was quickly emulated with regard to other "powers" such as China (Callahan \& Barabantseva 2011; Kavalski 2013), India (Hall 2015) or Japan (Zupančič \& Hribenik 2013). Again, intuitively an observer of international politics who is familiar with the uses of normative power outlined above would probably have fewer problems to see how India and Japan as democracies may fit the bill as well. Yet the fact that China shows 
Normative Powers and European Foreign Policy in a Minilateralist World (HELLMANN)

up prominently in some recent publications reemphasizes the "empty signifier" function of "normative power". Kavalski, for instance, introduced still another criterion for "normative power"-besides the ability to "shape what can be 'normal' in international life". In his view normative powers also had to express "a desire to be recognized" by others (Kavalski 2013: 258).

For my own purposes this is a helpful expansion of "normative power" usage since it redirects our attention to the fundamentally social or interactive nature of power (Jackson 1975). Still, because in this reading "recognition" is strongly associated with legitimacy, significant additional dimensions are still not sufficiently captured. Georg Jellinek, an influential Austrian legal scholar from the early decades of the $20^{\text {th }}$ century, has to offer some of these additional meanings when he speaks of "the normative force of the factual". This idea of "the factual" carrying "normative force" is based on the view that the "factual" is almost instinctively taken to be the "normal" and that both are deeply intertwined at the same time with the "normative" because fundamental socialization processes render us (as "social agents" and due to our cognitive capacities) to take the "factual", "normal" and "normative" as being separable at best for "analytical" purposes.

This idea of an innate "tendency of elevating the factual to the normal" while conceiving it at the same time as being inherently "normative" seems to be useful for analyzing contemporary EUropean foreign policy in the context of a broader "Normative Powers"-debate for two reasons. First, it links an expanded understanding of "normative power(s)" to previous usages of the concept in such a way that the lopsidedly positive semantic load is replaced with an understanding of "normativity" which allows for "good" as well as "evil" forces. In concrete terms: The EUropean Union, then, is as much a "normative power" as is Russia because both have issued powerful claims "to define what passes for "normal' in world politics" in the recent crisis over the annexation of 
Crimea and the war in Ukraine.

More provocatively still: Both the EU and the "Islamic State" exercise "normative power" in the sense that the "form of power (pouvoir)" they use is, at a minimum, as much "ideational" as it is "material or physical” (see Manners 2013: 308-309). The definitional criterion of power which Max Weber emphasized - ie. that the "chance of a man or of a number of men to realize their own will in a communal action" is realized "even against the resistance of others who are participating in the same action" (Weber et. al. 1946: 180) — this definitional criterion of power is much less helpful in analyzing these and other important conflicts in contemporary international politics because the number of cases of "great power" conflicts with clear-cut powerful winners are hard to identify even with regard to the most powerful players. Just on the sideline: this is one of the reasons why a book like the one which Moises Naim published (Naim 2013) has become a bestseller: the idea that "power" itself has "become perishable, transient, evanescent" resonates.

In sum: Rather than focusing on what is presumably the "correct" understanding of "normative" and/or "power" I am suggesting an approach which takes the uses of these concepts seriously while at the same time broadening the reach of conceptual investigations in order to recover buried meanings which can be useful analytically. This is an approach to concept formation (and therefore: "theorizing") which marries a Wittgensteinian approach with what the American pragmatist Richard Rorty calls "hermeneutics with polemical intent". My approach emphasizes (with Ludwig Wittgenstein (1958)) that the meaning of words and concepts lies in their uses while at the same time advocating what Rorty called being "hermeneutic about the opposition-trying to show how the odd or paradoxical or offensive things they say hang together with the rest of what they want to say, and how what they say looks when put in our own alternative idiom" (Rorty 1979: 365).

In such an understanding the particular attractiveness of the concept 
Normative Powers and European Foreign Policy in a Minilateralist World (HELLMANN)

of "normative powers" lies in the political struggles to which they point. The EUropean Union as a "normative power" is stuck in political struggles with "normative power Russia" and "normative power Islamic State" over what should (or: what must not) "pass for "normal". And it is in both regards - as much an "ideational" struggle as it has "material or physical" dimensions.

\section{European Foreign Policy as Boundary Drawing}

This brings us to the second key concept in my title, "European foreign policy", and how this concept hangs together with "normative power(s)". As in the case of "Normative Power Europe" I will try to show how a conceptual recontextualization of "European foreign policy" might also help to better understand EUrope's current predicament. This recontextualization will focus on the fact that the concept of "European foreign policy" points to both, the EU's expanding efforts to act as a single foreign policy actor and the renaissance of "foreign policy" (within) the European Union, ie. among its member states.

From a socialization point-of-view there are always two sides to look into if one wants to understand what is going on in EUropean affairs (and foreign policy) - what the EU is trying to do and what is done to the EU. Vis-à-vis its external environment the European Union is trying to shape collectively what may be acceptable as "normal" conduct in its "neighborhood". If one goes back to the early 1990s (ie. the time of the "end of the Cold War") and what followed in the subsequent two decades, the EU's power to shape its "neighborhood" via membership enlargement and association agreements has been quite impressive (Hellmann 2016a). Even the EU's fledgling military capacities have been expanded and put to good use as, for instance, in "Operation Atalanta" (Howorth 2014: 144-150).

However, the flipside of the socialization-coin is that the EU has also 
been at the receiving end of socialization attempts by other actorsand increasingly so during the last few years when the "common foreign and security policy" of the EU has ever more often fallen victim to novel external as well as internal forces. Externally it now faces the competing attempts (for instance by Russia or ISIS) to define what normality should amount to in a larger "neighborhood" region which includes Ukraine and the outliers of the Caucasus in the East and the Middle East and North Africa to the South.

Internally a "common foreign and security policy" of the EU has come under pressure from the foreign policy of its own member states. In some cases-but these are the less important ones-this is the oldfashioned unilateralism of individual members states acting in "the national interest" which undermines a common EU stance. The more critical cases are those where EU member states have, in recent years, ever more often yielded to other "factual" normative powers. As illustrations one could point to forces such as international financial markets (as in the so-called "Euro crisis" with Greece at its center), the "domestic" demands of "indigenous" electorates which call for a tightening of borders (as in the current refugee crisis) or the determined push of political classes in some of the more powerful member countries to obligate other EU members to show "solidarity" (as in Germany's push for a redistribution of refugees among EU members (Traynor \& Kingsley 2015) or France's push after the terrorist attacks in Paris in November to mobilize military support on the basis of Art. 42(7) of the Lisbon Treaty).

All this is "European foreign policy" in a very basic sense, especially if you operate with standard definitions of foreign policy such as the one offered by Christopher Hill:

A brief definition of foreign policy can be given as follows: the sum of official external relations conducted by an independent actor (usually a state) in international relations. The phrase 'an indepen- 
Normative Powers and European Foreign Policy in a Minilateralist World (HELLMANN)

dent actor' enables the inclusion of phenomena such as the European Union; external relations are 'official' to allow the inclusion of outputs from all parts of the governing mechanisms of the state or enterprise while also maintaining parsimony with respect to the vast number of international transactions now being conducted; policy is the 'sum' of these official relations because otherwise every particular action could be seen as a separate foreign policy - whereas actors usually seek some degree of coherence towards the outside world. Lastly, the policy is 'foreign' because the world is still more separated into distinctive communities than it is as single, homogenizing entity. These communities therefore need strategies for coping with foreigners (or strangers) in their various aspects (it should be noted that the word 'foreign' derives from the latin 'foris' meaning 'outside'). (Hill 2003: 3)

If, in contrast, one conceives of "foreign policy" not in terms of a static property of "states" in a so-called "Westphalian system" but, instead, in terms of an historically contingent political practice which creates and constantly reproduces "foreign" (and, for that matter, also "domestic") subjects in the first place, "European foreign policy" becomes a bundle of fascinating "boundary drawing performances" in Richard Ashley's sense:

Why not put aside our readiness to conceive foreign policy as action on the part of pre-given actors who have well-defined competencies and who respect pre-given boundaries of social and political action? ( ..) Why not understand foreign policy as a specific sort of interpretive performance whose overlapping effects include (a) the constitution and empowering of states and other subjects, (b) the defining of their socially recognized competencies, and (c) the securing of the boundaries that differentiate domestic and international, economic and social spheres of practice and, with them, the proper domains in which specific subjects may secure recognition and compe- 
『日本 $\mathrm{EU}$ 学会年報』第36号, 平成 28 年 4 月

tently act? In short, why not regard foreign policy as a specific kind of boundary producing political performance? (Ashley 1987: 53)

In Ashley's understanding foreign policy is "boundary drawing" both with regard to how the EU acts collectively vis-à-vis its "outside" and how its constituent parts (ie. member states) draw and redraw boundaries among themselves - ie. how they constitute one another as states, how they delimit their competencies, and how they define how the boundaries that differentiate domestic and international, economic and social spheres of practice are to be drawn (for a more detailed discussion see Hellmann 2016b).

Let me illustrate this perspective first with a brief look at the institutional structure of European foreign policy, and, secondly, with regard to three of the recent crises of foreign policy in the European Union.

As far as the institutional structure of the $\mathrm{EU}$ is concerned there is no need in this audience to go into much detail. Suffice it to say that over the past few decades the EU has built an impressive bureaucratic apparatus which resembles in many ways what we know from the classical "nation state" even though some of the traditional core competencies remain with the member states of the EU (see, for instance, Jun$\cos \&$ Pomorska 2015). Even though the EU obviously is not capable to cover the full range of typical foreign policy activities of nation states it does possess significant attributes of a typical foreign policy actor - including the capacity of recognizing and being recognized as a foreign policy actor diplomatically.

Let me briefly highlight three recent crises which shed some different light at "European foreign policy" and which also help to explain the EU's current predicament: the crisis which resulted from the Russian annexation of Crimea, the Euro-/Greek debts crisis, and the ongoing refugee crisis.

The crisis which resulted from the Russian annexation of Crimea and 
the break-out of war in Eastern Ukraine with Ukrainian militias being supported by Russia has shown both the limits and the relative strength of a common European stance. In the aftermaths of the annexation of Crimea the EU has not only reinforced the boundary vis-à-vis Russia-perhaps the single most important neighbor of the EU in the region encompassing Europe, the Middle East and North Africa. The crisis has also clarified the boundary between the EU and Ukraine. Most importantly it has shown the limits of the EU to stop a powerful and determined military aggressor while at the same time driving home the lesson to Russia in subsequent months that its disregard for International Law does have a price.

The second European foreign policy crisis of recent years, the Greek debts/Euro-crisis is normally not dealt with in terms of "foreign policy" because in the normal language of European politics this was, so to say, a "domestic" EUropean issue in the sense that it involved ministerial bureaucracies other than foreign ministries. Yet in the understanding of foreign policy I have suggested above with reference to Richard Ashley this crisis has been one of the most critical "foreign policy" crises in the EU's history because it mobilized internal boundary drawing practices among member states, esp. Greece and Germany which have not only undermined the cohesion of the Union by resurrecting nationalistic sentiments but which have also driven home the point that the normative power of the "solidarity"-clause in the Treaty of the European Union often reaches its limits at the border of the nation state (for a discussion of the legal force of the solidarity clause see Kadelbach 2014).

This applies equally to my third example, the recent refugee crisis with the only difference that it is now Germany which is calling for the "solidarity" of EU partners to share the burden. The fact that Germany finds limited resonance at best for its calls for solidarity does not only highlight the very different refugee "cultures" within the EU. It 
also underlines the Jellinekian "normative force of the factual" in the sense that the very fact of masses of refugees flooding into the EU has been widely perceived in European public opinion as a fundamental threat to established ways of life in addition to rapidly undermining both a key achievement of European integration, ie. the Schengen Agreement and cherished "liberal" asylum laws (for a more detailed discussion see Hellmann 2016c).

In sum: The analysis of European foreign policy at the institutional level of the Union as a whole and with regard to the day-to-day practice of foreign policy as a boundary producing political performance of constituting "insiders" and "outsiders" has highlighted both the ambivalence of and the clashes between different normative powers. It has not only accentuated the boundary between EUropeans and non-EUropeans but also reintroduced EUropeans to one another as "foreigners".

\section{The European Union in a Minilateralist World}

My third key term, minilateralism, is best introduced via its much better known opposite, multilateralism. Given the penchant for definitional (rather than Wittgensteinian) approaches to concept formation in Political Science in general and International Relations in particular the very sparse (and almost "Realist") definition of "multilateralism" once suggested by Robert Keohane-he defined multilateralism as the "practice of coordinating national policies in groups of three or more states" (Keohane 1990: 731) - may reflect mainstream understandings of the concept but certainly does not exhaust the meaningful semantic content of it.

John Ruggie made a very different and historically grounded suggestion some twenty years ago to conceive of multilateralism instead as a distinct and "generic" form of interstate collaboration based on "generalized principles of conduct" such as (1) the indivisibility of certain 
Normative Powers and European Foreign Policy in a Minilateralist World (HELLMANN)

goods (eg. peace) (2)non-discrimination (as in trade agreements) or (3) diffuse reciprocity, ie. arrangements in which participants focus less on immediate and direct benefits in the form of specific quids-pro-quos than on roughly equivalent benefits in the aggregate and over time (Ruggie 1992: 571-572).

If you are willing to work with Ruggie's understanding you will probably immediately accept that the European integration project is the most successful experiment in the history of the "Westphalian state system" which has institutionalized multilateralism. To be sure: multilateralism has been a celebrated feature of the so-called "liberal world order" and therefore figured prominently also in other international institutional settings after 1945 (see Hellmann 2013: 103-110). Yet nowhere was an integration project based as much on the foundational social practice of diffuse reciprocity - which we normally observe only in tighter social groups - as in the European Union.

It is against this background that the spread of "minilateralism" is particularly worrisome. The neologism "minilateralism" is a creation of Moises Naim (2009) which is obviously meant to set a counterpoint to "multilateralism". In Naim's positive connotation "minilateralism" describes a framework of cooperation which gets together the "smallest possible number of countries needed to have the largest possible impact on solving a particular problem. Think of this as minilateralism's magic number."

There is nothing wrong per se with minilateral cooperation. Who could be against "cooperation"! The problem is that the smallest possible number for effective problem-solving quickly grows very large - and increasingly so if one looks around at the current menu of crises. Consider, for instance, the number and political weight of countries needed to effectively address the problems associated with the civil war in Syria. Moreover, the minimum number of countries required to effectively regulate global warming does not look any more encouraging. In other 
words, minilateralism suggests quick fixes in ad-hoc diplomatic settings at the expense of longer-lasting and broader sets of mutually binding institutional arrangements. It privileges sovereignty and power-and it disadvantages the weak.

Although the champions of state sovereigntism among the so-called BRICS states have been pushing hardest for minilateralism Western (and EUropean) powers have contributed to its spread as well during the past decade by circumventing formalized institutions and processes with "coalitions of the willing" and ad-hoc "contact groups" (Hellmann 2013: 107-110). In other words: the West itself has undermined the very multilateral arrangements which had rendered segments of the post-War international order into more reliable cooperative settings, such as the United Nations, or into islands of peaceful change, such as the zone of European integration.

If this represents an adequate interpretation of global trends the implications for the EU in general, and European foreign policy in particular, spell additional trouble in two ways. To the extent that the larger member states (eg. France and Germany) fall prey to the lures of minilateralist steering attempts by other great powers the cohesion of the Union will further suffer. More basically still, the normative force of spreading minilateralism undermines the very idea of European integration because this project has been built on generalized principles of conduct which Ruggie's concept of multilateralism rightfully stresses.

\section{Conclusions}

EUrope and its key member states may well face "decline" (as Kenneth Waltz pointed out three years ago). Yet, compared to Waltz's analysis in 2013 Europe's "peace" looks much more precarious today and the overall "state of the Union" much less "boring" and "happy". The EU does not face just one more of those crises which it has successful- 
Normative Powers and European Foreign Policy in a Minilateralist World (HELLMANN)

ly mastered in the past decades - and as a result of which it has moved "forward" in either expanding its reach (by drawing in new members or associates) or deepening integrative structures (via a "common foreign and security policy", the creation of the European External Action Service, or the banking union). The core predicament of the European Union today is that the proliferation of external and internal crises within the EU and in EUrope's "neighborhood" have undermined fundamental institutional routines and established practices. What is more: it has for the first time shattered the belief that the project of European integration is irreversible.

Other powers (ie. collective actors such as "great powers" or "factual powers" such as refugees or populist electorates) encroach ever more successfully in defining what is "normal" in issue areas and/or regional contexts where the European Union and its member states were able to shape things much more to their liking in the past. Whereas "Normative Power Europe" succeeded remarkably as a collective actor in defining what passes for "normal" during the first decade after the end of the Cold War ("Eastern Enlargement", "European Neighborhood Policy" (ENP) etc.) the past few years have seen a much more defensive EU which increasingly had to adjust (at least gradually) to the normative "normality" standards either set by outsiders (eg. Russia, Turkey, Syria/ISIS terrorists) or by internal forces seeking to undermine or reverse what had been achieved in past rounds of deepening integration (eg. Germany's push for strengthening intergovernmental mechanisms in financial matters or the British push towards re-nationalizing EU competencies).

In other words: "European foreign policy" as boundary producing political performance by ever more "foreign policy" actors at different societal levels faces a multitude of normative or factual powers for which it is not (yet) well prepared. The predicament looks stark because some of the more clearly "external" and collective challenges of "Euro- 
pean foreign policy" (Ukraine/Crimea) have thus far been handled reasonably successful whereas the resurgence of varied forms of national boundary drawing within the EU (eg. Germany's austerity push and Greek debt-rescheduling; the British referendum; and uncoordinated refugee policies) have touched and highlighted diverging core "national interests" or "national" identity markers. The latter is particularly worrisome because it boils down to an almost cancerous spread of minilateralist practices at the very heart of a European Union which hitherto figured as an exemplar institution of lived multilateralism. The dangers of infection were real already for some time (and clear to see for anyone who cared about the broader "liberal world order"). They have increased in recent months as a result of the refugee crisis because they have not only further damaged the trust in European institutions and solidarity but also shattered the sense that the political classes in Berlin, Paris or Athens are capable of securing the treasured ways of life in Germany, France or Greece.

The EU is not yet "doomed" (as some say). However, it does face the most serious accumulation of deep crises since the beginnings of the European integration project. If it is to become stronger as a result of this crisis (as it has so often in previous ones) a lot more joint political leadership and multilateral collaboration will be needed than is currently on display.

1) This manuscript has been submitted in this form on 26 January 2016. This Keynote was given on 21 November 2015 at Kansai University, Osaka. I am grateful to the organizers of the conference, especially Professor Yuichi Morii, for providing the opportunity to reengage with a topic of research which I had neglected in recent years. Thanks also to Daniel Fehrmann for research assistance and technical support.

2 ) Since "Europe" encompasses, at least geographically, states beyond the European Union (such as Ukraine, Belarus, parts of Russia and South-Eastern Europe) I will use 'EUrope' and 'EUropean' to clarify when I am only referring to the EU part of Eu- 
Normative Powers and European Foreign Policy in a Minilateralist World (HELLMANN) rope.

3 ) The only reference to "normality" in his 2013 article was in the context of a reference to the work of Roland Bleiker and "narrative norms" in so-called "postmodern science" which were said to "legitimate certain narratives and recognize that the ability to define normality interferes with virtually all aspects of the international'" (Manners 2013: 313 quoting Bleiker 1998: 447).

4) Jellinek (1914: 337-339): „Der Mensch sieht das ihn stets Umgebende, das von ihm fortwährend Wahrgenommene, das ununterbrochen von ihm Geübte nicht nur als Tatsache, sondern auch als Beurteilungsnorm an, an der er Abweichendes prüft, mit der er Fremdes richtet. Man muß dabei nicht sofort an das Ethische und Juristische denken; bereits in den tausendfältigen Normen, die das tägliche Leben bildet, in den Werten, die in Verkehr und Sitte herrschen, kommt das zum Ausdruck. Schmackhaft dünkt den meisten Menschen die heimatliche Zubereitung der Nahrung, schon der Typus des eigenen Stammes, löblich die Vorurteile des Kreises, dem man angehört, richtig die Lebensweise der Gesellschaftsklasse, der man sich zuzählt. ( ...) Noch schärfer tritt aber das Verhältnis des Faktischen zum Normativen in der Entstehung des Rechtes hervor. Alles Recht in einem Volke ist ursprünglich nichts als faktische Übung. Die fortdauernde Übung erzeugt die Vorstellung des Normmäßigen dieser Übung, und es erscheint damit die Norm selbst als autoritäres Gebot des Gemeinwesens, also als Rechtsnorm."

\section{References}

Aggestam, L. (2008). “Introduction: ethical power Europe?”, in International Affairs, 84(1), pp. 1-11.

Ashley, R. K. (1987). "Foreign Policy as Political Performance", in: International Studies Notes, 13 , pp. 51-54.

Bleiker, R. (1998). "Retracing and redrawing the boundaries of events: postmodern interferences with international theory", in: Alternatives: Global, Local, Political, 23(4), pp. 471-497.

Bull, H. (1982). "Civilian Power Europe: A Contradiction in Terms?”, in Journal of Common Market Studies, 21 (1, 2), pp. 149-164.

Callahan, A. W., and Barabantseva, E. (eds.) (2011). "China Orders the World: Normative Soft Power and Foreign Policy". Washington, D. C: Woodrow Wilson Press.

Carta, C. (2014). "Use of Metaphors and International Discourse: The EU as an Idiot Power, a Deceptive Pangloss and a Don Juan in his Infancy", in: Cooperation and Conflict, 49(3), pp. 334-53.

Chandler, D. "Semiotics for Beginners"; available at http://visual-memory.co.uk/daniel/Documents/S4B/sem-gloss.html\#empty_signifier (13 November 2015). 
『日本 $\mathrm{EU}$ 学会年報』第36号, 平成 28 年 4 月

Damro, C. (2012). “Market Power Europe”, in: Journal of European Public Policy, 19(5), pp. 682-99.

Gerth, H. H., and Mills, C. W. (eds. \& trans.) (1946). "From Max Weber: Essays in sociology". New York, NY: Oxford University Press.

Google Scholar. "Entry 'Ian Manners〉 normative power europe 〈"; available at https:// scholar.google.de/scholar?hl=de\&q=Ian + Manners $+\%$ 22normative + power + europe $\%$ $22 \& b \operatorname{tnG}=\& l r=(24$ January 2016).

Hall, I. (2015). “Normative Power India?”, in J. Gaskarth (ed.), China, India and the Future of International Society (pp. 89-104). Boulder, CO: Lynne Rienner.

Hellman, G. (2013). “Liberal Foreign Policy and World Order Renewal”, in S. Benhabib, D. Cameron, A. Dolidze, G. Halmai, G. Hellmann, K. Pishchikova, and R. Youngs, The Democratic Disconnect. Citizenship and Accountability in the Transatlantic Community (“Collaborative Report”). Washington, DC: Transatlantic Academy, pp. 101-112.

Hellmann, G. (2016a, forthcoming). "Defending the 'West'? The Transformation of National Security in the European Union", in G. Hellmann, and B. Herborth (eds.), Uses of the West. Cambridge: Cambridge University Press.

Hellmann, G. (2016b, forthcoming). "Foreign Policy: Concept, Vocabulary and Practice”, in G. Hellmann, A. Fahrmeir, and M. Vec (eds.), The Transformation of Foreign Policy: Drawing and Managing Boundaries from Antiquity to the Present. Oxford: Oxford University Press.

Hellmann, G. (2016c, forthcoming). “Germany's world. Power and followership in a crisisridden Europe”, in Global Affairs, 2(1).

Hill, C. (2003). "The Changing Politics of Foreign Policy". Houndmills Basingstoke: Palgrave Macmillan.

Howorth, J. (2014). "Security and Defence Policy in the European Union". Houndmills, Basingstoke: Palgrave Macmillan.

Hyde-Price, A. (2008). "A 'Tragic Actor'? A Realist Perspective on 'Ethical Power Europe”, in: International Affairs, 84(1), pp. 29-44.

Jackson, J. (1975). "Normative power and conflict potential", in Sociological Methods \& Research, 4(2), pp. 237-239.

Jellinek, G. (1904). „Allgemeine Staatslehre“. Berlin: Häring.

Jørgensen, K. E., and Laatikainen, K. (2004). „The EU and the UN: multilateralism in a new key ?". Paper presented at the Second Pan-European Conference of the Standing Group on EU Politics, Bologna, 24-26 June; available at http://www.jhubc.it/ecpr-bologna/docs/293.pdf (22 September 2010).

Juncos, A., and K. Pomorska. (2015). "The European External Action Service.", in K. E. Jorgensen, A. Aarstad, K. Laatikaainen, E. Drieskens, and B. Tonra (eds.), The SAGE Handbook on European Foreign Policy. London: Sage Publications. 
Normative Powers and European Foreign Policy in a Minilateralist World (HELLMANN)

Kadelbach, S. (ed.). „Solidarität als Europäisches Rechtsprinzip?“. Schriften zur Europäischen Integration und Internationalen Wirtschaftsordnung, 32. Baden-Baden: Nomos Verlagsgesellschaft.

Kavalski, E. (2013). "The Struggle for Recognition of Normative Powers: Normative Power Europe and Normative Power China in Context", in Cooperation and Conflict, 48(2), pp. 247-267.

Keohane, R. (1990). “Multilateralism: An Agenda for Research”, in International Journal, 45(4), pp. 731-764.

Koops, J. (2011). "The EU as an Integrative Power: Assessing the EU's effective multilateralism with NATO and the United Nations". Brussels: VUB Press.

Manners, I. (2002). "Normative power Europe: a Contradiction in Terms?", in: Journal of Common Market Studies, 40(2), pp. 235-58.

Manners, I. (2013). "Assessing the decennial, reassessing the global: Understanding European Union normative power in global politics", in: Cooperation and Conflict, 48, 304329

Manners, I. (2015). "Sociology of Knowledge and Production of Normative Power in the European Union's External Actions", in: Journal of European Integration, 37(2), pp. 299-318

Morgenthau, H. (1985 [1948]). "Politics among Nations". New York: Knopf.

Naim, M. (2009). “Minilateralism. The Magic Number to Get Real International Action”, in Foreign Policy, July/August 2009, pp. 5-8; available at http://www.foreignpolicy.com/articles/2009/06/18/minilateralism (10 December 2012).

Naim, M. (2013). "The End of Power. From Boardrooms to Battlefields and Churches to States. Why Being in Charge isn't what it Used to Be”. New York: Basic Books

Pardo, R. P. (2011). “Normal Power Europe. Non-Proliferation and the normalization of EU' s foreign policy", in: Journal of European Integration, 34(1), pp. 1-18.

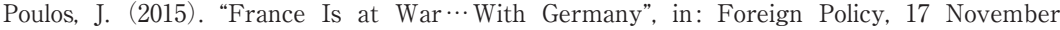
2015, available at https://foreignpolicy.com/2015/11/17/france-is-at-war-with-germany-isiseurope/ (21 November 2015).

Rorty, R. (1979). "Philosophy and the mirror of nature". Princeton: Princeton University Press.

Ruggie, J. G. (1992). Multilateralism: The Anatomy of an Institutional Form, in: International Organization, 64(3), pp. 561-598

Sjursen, H. (2006). "The EU as a 'normative' power: how can this be?", in: Journal of European Public Policy, 13(2), pp. 235-251

Steinmeier, F.-W. (2015). "A world out of joint: What binds us together? The international order 70 years after the founding of the United Nations". Speech by Foreign Minister Frank-Walter Steinmeier on the 70th Anniversary of the United Nations, 
『日本 $\mathrm{EU}$ 学会年報』第36号, 平成 28 年 4 月

Freie Universität Berlin, 21 October 2015; available at http://www.auswaertiges-amt. de/EN/Infoservice/Presse/Reden/2015/151021_FU.html (8 November 2015).

Traynor, I., and Kingsley, P. (2015). "EU governments push through divisive deal to share 120,000 refugees”, in The Guardian, 22 September 2015; available at http:// www.theguardian.com/world/2015/sep/22/eu-governments-divisive-quotas-deal-share120000-refugees (19 December 2015).

Wagner, W. (2015). “Liberal Power Europe”. Paper prepared for presentation at the 22nd International Conference of Europeanists, Paris, 8 July 2015.

Waltz, K., and Simon, L. (2013). "Interview with Kenneth Waltz", 15 March 2013; available at http://www.europeangeostrategy.org/2013/03/interview-kenneth-waltz/ (2 April 2013).

Wittgenstein, L. (1958). "Philosophical Investigations", translated by G. E. M. Anscombe. Oxford: Basil Blackwell.

Wood, S. (2009). "The European Union: a Normative or Normal Power?", in European Foreign Affairs Review, 14, pp. 113-128.

Xiaoyu, P. (2012). "Socialisation as a Two-way Process: Emerging Powers and the Diffusion of International Norms", in: The Chinese Journal of International Politics, 5, pp. 341-367.

Zupančič, R., and Hribenik, M. (2013). “Normative Power Japan: The European Union's Ideational Successor or another 'Contradiction in Terms'?”, in: Romanian Journal of Political Sciences), 13(2), pp. 106-136. 